\title{
MIGRATION AND COMMUTING IN THE AREAS OF INFLUENCE OF THE BRAZILIAN METROPOLISES
}

https://doi.org/10.4215/rm2019.e18017

\author{
Carlos Lobo ${ }^{a^{*}}$ - José Marcos P. da Cunha ${ }^{b}$
}

(a) Doutor em Geografia. Professor Universidade Federal de Minas Gerais, Belo Horizonte (MG), Brasil.

ORCID: https://orcid.org/0000-0002-5368-8879. LATTES: http://lattes.cnpq.br/5261484949232779.

(b) Doutor em Demografia. Professor Universidade de Campinas, Campinas (SP), Brasil.

ORCID: https://orcid.org/0000-0001-7097-364X. LATTES: http://lattes.cnpq.br/6443244380596194.

\author{
Article history: \\ Received 6 May, 2019 \\ Accepted 31 May, 2019 \\ Published 15 August, 2019
}

\section{(*) CORRESPONDING AUTHOR}

Address: Av. Presidente Antônio Carlos, n.6.627. CEP: 31270901 - Belo Horizonte (MG), Brasil. Tel (+55 31) 34095431

E-mail: carlosfflobo@gmail.com

\section{ABSTRACT}

At various moments in time, population mobility has served as a driving source of profound social and economic transformations in the regions of origin and destination in Brazil, not only as a consequence of structural needs. In addition to the traditional migratory flows, commuting mobility has also assumed an important role in the process of production and organization of spaces, especially at the regional level. Considering this aspect, this paper aims to evaluate the influence of migration on the phenomenon of commuting in the Areas of Influence (AI) of the main Brazilian metropolises, based on the sample microdata from the 1980 and 2010 Demographic Censuses. In a first approach, comparing these two census decades, the results show that there was a significant increase in the incidence of commuting, both in terms of volume of people and regarding the number of vectors. In addition to this fact, the data also allow us to observe that there is a considerable decrease in the proportion of the decade's migrants in intra-regional commuting, as well as an increase in the share of natives from the city where they live in the composition of these commuting movements.

Keywords: Migration, Commuting Mobility, Metropolitan Areas of Influence.

\section{RESUMO / RESUMEN}

\section{MIGRAÇÃO E MOBILIDADE PENDULAR NAS ÁREAS DE INFLUÊNCIA DE METRÓPOLES BRASILEIRAS}

\begin{abstract}
Em vários momentos no tempo a mobilidade populacional serviu como fonte motora de profundas transformações sociais e econômicas nas regiões de origem e destino no Brasil, não sendo apenas consequência das necessidades estruturais. Além dos tradicionais fluxos migratórios, a mobilidade pendular também tem assumido papel relevante no processo de produção e organização do espaço, especialmente no nível regional. Considerando essa dimensão, esse trabalho tem como objetivo avaliar a participação da migração na pendularidade nas Áreas de Influência (AIs) das principais metrópoles brasileiras, tendo como base os microdados amostrais dos Censos Demográficos de 1980 e 2010 . Em uma primeira aproximação, comparando essas duas décadas censitárias, os resultados demonstram que ocorreu um expressivo crescimento na intensidade da mobilidade pendular, tanto em termos de volume de pessoas quanto em relação ao número de vetores. Além desse fato, os dados também permitem observar que houve uma queda considerável na proporção dos migrantes da década na mobilidade pendular intrarregional, bem como um aumento do peso dos não migrantes naturais do município de residência na composição desses deslocamentos.
\end{abstract}

Palavras-chave: Migração, Mobilidade Pendular, Áreas de Influência Metropolitana.

\section{PARTICIPACIÓN DE LA MIGRACIÓN EN LA PENDULARIDAD EN LAS ÁREAS DE INFLUENCIA DE METRÓPOLIS BRASILENAS}

En varios momentos en el tiempo la movilidad poblacional sirvió como fuente motora de profundas transformaciones sociales y económicas en las regiones de origen y destino en Brasil, constituyéndose no solamente una consecuencia de las necesidades estructurales. Además de los tradicionales flujos migratorios, la movilidad pendular también ha asumido un papel relevante en el proceso de producción y organización del espacio, especialmente a nivel regional. Considerando esta dimensión, este estudio tiene como objetivo evaluar la influencia de la migración en el fenómeno de la pendularidad en las Áreas de Influencia (AIs) de las principales metrópolis brasileñas, teniendo como base los microdatos de la muestra de los Censos Demográficos de 1980 y 2010. En una primera aproximación, comparando las dos décadas censales consideradas, los resultados demuestran que ocurrió un expresivo crecimiento en la incidencia de la movilidad pendular, tanto en términos del volumen de personas, cuanto en relación al número de flujos establecidos. Además de este hecho, los datos también permiten observar que hay una reducción considerable en la proporción de los migrantes de la década que realizan la movilidad pendular intrarregional, así como un aumento del peso de los no migrantes naturales del municipio de residencia en la composición de esos desplazamientos.

Palabras-clave: Migración, Movilidad Pendular, Áreas de Influencia Metropolitana. 


\section{INTRODUCTION}

Despite the recent nature of the urbanization process in Brazil, which has intensified since the second half of the last century, the data from the last demographic censuses do not confirm the supposed thesis of spatial deconcentration of the population, nor demetropolization, as some hastier analyzes might suggest. In actual fact, the chief metropolitan centers maintained their demographic expression and continued to attract significant contingents of the population, although controversies persist about the occurrence of a supposed spatial dispersion (AZONI, 1986; DINIZ, 1993; MARTINE, 1994; MATOS, 1995; CUNHA, 2003 and 2015; LOBO, 2009; LOBO and MATOS, 2011). Nevertheless, given the current complex demographic dynamics, some issues are still noteworthy, such as the real magnitude and social significance of the various forms of associated mobility, such as commuting and migration. In this sense, an analysis of the spatial distribution of the commuting flows and vectors within the Metropolitan Regions may offer relevant additional clues to the study of the organization of elements in the territory, particularly when evaluated in parallel with migratory movements.

In the last decades, the population has risen significantly in many Brazilian municipalities in the metropolitan periphery, often as the result of the large volume of migrants from the respective urban nuclei, such as the MRSP or MRBH, which incorporate other dimensions than the so-called peripherization of poverty through migration (MATOS et al., 2003, CUNHA (org.), 2018). Historically, the process of expansion of the metropolitan spatial fabric is linked to the diffusion of strong commuting currents coming from the peripheral municipalities of the metropolitan regions. As a result, large waves of people were induced to commute, mainly due to the need for a workforce in the regional center or the attractiveness of the educational market. Although it is a typical phenomenon in the metropolitan context, commuting is not unique to this space. It also takes place outside metropolitan regions, involving major regional and local hubs, as well as in rural areas, evidencing distinct and equally important dimensions and facets of the population's spatial mobility.

Conceptually, commuting refers to the regular, usually daily, movement of individuals from their homes to where they work or study. Unlike migration, these displacements do not involve moving the place of residence, but rather a relatively regular flow from residenceÛwork/study (hence the frequent allusion to a commuting movement). Therefore, commuting is a phenomenon that is manifest and materializes in time and space, the result of a social and economic structure that reproduces itself in different political conjunctures. Analyzing commuting dynamics involves the investigation of relationships that are established at local, regional, and national scales, favoring combinations and distinctions of population movements that are evidenced in increasingly expanded and integrated spaces.

However, sometimes this mobility is perceived as a phenomenon associated with the migratory dynamic itself; a direct consequence of "unsuccessful" migrations, characterized by migrants who fail to establish themselves in their destination. To a great extent, this apparent "failure" may be because these migrants are not absorbed by the labor market and / or do not have access to the real estate market in the metropolitan nucleus. Their mobility is a manifestation of the imposition of the mechanisms of production and appropriation of space, which induce different forms of social segregation. This hypothesis raises some questions related to the comprehension of spatial mobility: what is the real magnitude of the relationship between migration and commuting? Are these commuting movements predominantly composed of migrants? If so, what is the prevalence of non-native and migrant workers of the decade in the group who regularly travel to another municipality for work and / or study purposes? Are there any changes in this pattern when comparing census data for 1980 and 2010? In which regions do native and non-migrant people predominate among the commuters? Taking these questions as a basis for reflection, the main objective of this paper is to evaluate the participation of migration in commuting movements in the Areas of Influence of the principal Brazilian metropolises, based on the flows extracted from the 1980 and 2010 Demographic Census sample microdata.

In addition to a strictly demographic meaning, the study of different forms of population displacement, such as migration and commuting, offers essential insights into the dynamics of spatial production. For example, it provides clues about the relationships established by the labor market, which define the capacity of retention and attraction of labor, and the quality and comprehensiveness of the educational system. In turn, the educational system caters to students in different levels of education, 
and ultimately defines the traits established in social and economic networks. Moreover, it reflects the emergence and consolidation of the force of attraction exerted by new regional centralities, as well as the possibilities / restrictions of residential location, due to the effects of land prices. Therefore, the analysis of commuting and migration enables the evaluation of the social aspects and dimensions relevant to public management and territorial planning, providing useful information for decision making and public policymaking, as potentially they can assist in proposing measures to reduce the adverse effects of regional inequalities in the country.

\section{METROPOLITAN DEMOGRAPHIC DYNAMICS: THE EVIDENCE AND MEANINGS OF MIGRATION AND COMMUTING}

The interpretation of reality offered by theoretical models designed for highly developed countries collides with the singularity and complexity that mark the formation of territory and the organization of national space. The process of urbanization in Brazil began to take shape in the 1940s when fragile industrialization induced a spatial reorganization of the population in the national territory; the main centers of the urban network formed in the country were concentrated in the Southeast. These changes occurred despite the governmental policies and endeavors to promote the opening of agricultural frontiers from the 1930s onwards (MARTINE, 1987; PATARRA, 1984; TASCHNER and BÓGUS, 1986). In contrast, the rural population had declined since the 1950 s, so that by 1970 , the urban population already accounted for about $56 \%$ of the total population in Brazil. In the same period, this proportion reached $72.7 \%$ in the Southeast. The increase in rural-urban migration flows intensified the process of urban population growth, heavily concentrated in the main Brazilian state capitals, forming large complex urban agglomerations, through the processes of metropolization and conurbation.

For Matos and Baeninger (2004, p.14), until the 1970s, the general population displacement trends in Brazil were anchored in the following axes: first, the massive transfer of the rural population to urban spaces, which contributed to the emptying of the countryside. The second tendency was the migration to agricultural frontiers, and the third was the intense phenomenon of metropolization and urban concentration. In 1970, for example, just over $25 \%$ of the Brazilian population lived in the principal metropolitan regions. This share rose to about $48 \%$ in 2010. Part of the increase in the relative weight represented by the stocks of the resident population in these spaces resulted from the creation of new metropolitan regions, or the incorporation of new municipalities into existing metropolises. However, at least until the 1980s, the growing contingent of migrants moving to metropolitan areas exposed a striking feature of the spatial distribution of the Brazilian population: the intense demographic concentration in space.

In the national literature, there is a broad theoretical and conceptual investment in the urbanization process in Brazil, as well as its impacts on the living conditions of the population and regional metropolitan forms and arrangements. As pointed out by Reis (2006), the meaning of urbanization varies on the different spatial levels and involves diversity and articulation in urban and regional spaces, which requires the incorporation of the analysis of the relationship between center and periphery, in its multiple scales. The urban dispersion process, typical, but not exclusive to the Brazilian case, is characterized by the fraying of the urban fabric, with urbanization extending throughout the territory, including urban nuclei separated by interstitial voids, which maintain close links and a single urban system. Constellations or nebulae of urban nuclei of different sizes are formed, integrated with metropolitan and sub-metropolitan urban agglomerations, where the interregional transport system is used for daily transport (REIS, 2006).

Limonad (2007) argues that despite the spread of urban sprawl in various parts of the world, forms of intensive urbanization persist. Even though both dispersive and intensive forms lead to the territorial expansion of the urban fabric, their final form differs. The ragged, fragmented and pulverized urban fabric of extensive urbanization, characteristic of what Francesco Indovina called the "metropolitan archipelago," is countered by large high-density urban agglomerations, reinforcing the primacy of the metropolis and the concentrated and compact city. In Brazil the location of this dispersion has various manifestations, either as a form of expansion of the metropolitan peripheries, or 
by the dispersed multiplication of small urban agglomerations in employment basins, or in the form of industrial, service or tourist clusters, often accompanied by the emergence of condominiums or mega-condominiums outside urban areas (LIMONAD, 2007). Cruz (2010) believes that the definition of the Metropolitan Region as a framework for public policy implementation presents obstacles, given that there are significant internal differences, including the level of interaction between metropolitan municipalities. For this author, there is a deadlock regarding the appropriate unit (cutout) for planning in the metropolitan ambit. Most of the time, the starting point is an a priori definition of the territory, rather than an analysis in which commuting journeys define the extent of the area to be considered as dispersed (OJIMA, 2011)2.

Taking into account not only commuting but also the processes of territorial and spatial reconfiguration of the metropolises and their regions of influence as ways to delimit dispersed areas, renders the concept of the city-region essential. According to Lencioni (2000), when analyzing the case of São Paulo, contemporary socio-spatial processes of regional dispersion, in which the mechanisms of productive restructuring and regional integration operate, cause a territorial split of industries in the metropolitan area. It is germane to understand the city-region as a configuration of the socioeconomic and socio-spatial processes typical of contemporary times, a concept that fits the context of metropolitan population dispersion, processes that can be evidenced by migration and commuting (LENCIONI, 2000). These dynamics and their specificities in the context of São Paulo were analyzed in some demographic studies, such as those by Cunha et al. (2013), Silva, Cunha and Ortega (2017) and Silva (2018). They demonstrate the concomitance of "traditional," and undoubtedly metropolitan processes with "extra-regional" articulations, strongly suggesting a new formation that extends the scope of urban expansion and the spatial redistribution of the population, establishing what has been called the "Paulista Macro-metropolis" (CUNHA et al., 2013).

Migration analysis offers an additional approach to more specific social processes by incorporating aspects of demographic dynamics into the spatial dimension. It allows the assessment of flows at national, regional, and local levels, going beyond an indicator of concentration or dispersion of economic activities. It also identifies the rural and urban development profile, the institutional and social forms of dissemination of information and innovations, the late or advanced insertion into demographic transition and the degree of regional inequality when discussing the end of the concentrating pattern of activities. For Matos (2003), visibility should be given to recent changes in Brazilian migratory patterns, which evidence the secondarization of flows from the countryside to the cities and the increasing complexity of the urban network, apparent signs of an increase in some positive externalities on the periphery and new migratory flows that are already heading to the medium-sized cities.

Commuting exhibits the more fluid aspects of demographic dynamics, although it enables the degree of regional integration to be assessed. Despite the tendency for denser spaces to have more intense relationships with the metropolitan core, territorial densification enhances social and economic relationships in metropolitan spaces, which may impact on the reduction of transport costs and the expansion of infrastructure, boosting the population's spatial mobility. In this respect, commuting can be regarded as a consequence of metropolitan mobility, determined by the increase of the expansion vectors of the urban fabric beyond the metropolitan cores. This reflects not only the residential choices of segments of the population in the expectation that positive externalities will outweigh the additional costs of the distance from work but also the exclusionary action of the housing and / or labor market, in the case of low-income workers, ( BRITO and SOUZA, 2005) 4.

According to Pereira and Herrero (2009, p. 22), there are also "productive deconcentration commuting flows," which indicate "a possible process of multi-polarized metropolitan integration, reinforcing the dynamization of the region's economic sub-centers and pointing out new axes of urban sprawl and road demand." If some municipalities "benefit" from the temporary increase in population, given the increased demand for various local services, others are very different outside the working day, as is the case of "dormitory cities." Since the final decades of the last century, these cities have been a matter of concern given their "less lively" setting from the urbanist point of view. Precarious urban infrastructure, irregular land occupation and the high volume of low-skilled workers, as well as a landscape dominated by unfinished housing, are features that mark the peripheries of Brazilian metropolises (LOBO, 2016)s. 


\section{THE REGIONAL CUOUTS, DATABASES AND METHODOLOGICAL PROCEDURES USED}

The urban hierarchal levels and the definition of the regions of influence of the Brazilian cities were extracted from previous analyses conducted by the IBGE, which were based on questionnaires that investigated the intensity of consumer flows in search of goods and services in the years 1966, 1978 and 1993. The current regionalization proposal (REGIC 2007), published in 2008, resumes the original design used in the first IBGE studies, which resulted in a classic study: Brazil's division into functional urban regions, in 1972.

The theoretical support presented by the REGIC 2007, favored the concept of management of the territory, first defined by Corrêa (1995). According to this author, the center of territorial management is the location of both the various state agencies and the headquarters of companies whose decisions directly or indirectly affect a given space that is controlled by the city. Based on this concept, REGIC 2007 considered two levels of administrative centrality when defining the hierarchy of the city network: the Federal Administration, measured by the existence of organs of the Executive Power and the Federal Judiciary; and Business Administration, which refers to the presence of different facilities and services (commerce and services, financial institutions, higher education, health, internet, open television networks and aerial connections)6.

The delimitation of the Regions of Influence in the national territory created a total of 711 administrative centers, which were classified into six levels of hierarchy, according to their position in the respective federal and corporate administration ambits. The areas of influence and the articulation of networks of cities were established according to the intensity of the links between them, identified using secondary data and information obtained by a specific research questionnaire. In the end, cities were classified into five primary hierarchal levels: Metropolises; Regional Capitals; Subregional Centers; Zone Centers; and Local Centers.

For this study, the spatial cutouts were defined using the aggregation of the municipalities in the Areas of Influence (AIs) of the main Brazilian metropolises according to Complementary Law $\mathrm{N}^{\circ}$ 14/1973 and the political-administrative divisions of 1980 and 2010. Namely: Belém, Belo Horizonte, Cuiabá, Curitiba, Fortaleza, Porto Alegre, Recife, Rio de Janeiro, Salvador, and São Paulo?. The AIs of Manaus and Brasilia were also included, due to their demographic, economic, and regional relevance. The boundaries of each of these areas are shown in Figure 1. The most noteworthy in terms of size is the AI of São Paulo, with $24.95 \%$ of the population, $16.06 \%$ of the municipalities and $8.89 \%$ of the country's area. The AIs of Fortaleza and Rio de Janeiro are also remarkable, mainly due to the high volume of the resident population. In the case of Fortaleza, the percentage of municipalities and the area of the national territory are $14.43 \%$ and $9.30 \%$ of the national total, respectively.

Data on commuting and migration were extracted from the 1980 and 2010 demographic census sample microdatas. The origin and destination matrix that establishes the commuting flows is the combination of the variables that identify the municipality of residence on the reference date of each census and the municipality of study and / or work declared9. For those classified as commuters, the definition of migrant and non-migrant is given by the last step migration variable, when the census informed a municipality of previous residence different from that of the current residence10. Next, in a complementary categorization, migrants and non-migrants were differentiated into native and non-native, this was defined when the municipality of residence and birth coincide. This procedure enabled the identification of four hybrid commuting categories: (1st) non-native migrants and (2nd) native migrants; (3rd) non-native non-migrants and (4th) native non-migrants.

The commuting flows were broken down into each of these four categories and also analyzed considering three spatial groupings of origin and destination: the Metropolitan Nucleus (MN), the Metropolitan Periphery (PM) and the Interior of each Area of Influence (IAI). This resulted in a matrix of municipalities "i", distributed in regions " $\mathrm{j}$ ", which represents the commuting journeys, identified by the displacement from the municipality of residence to work or study in each of the AIs. Thus, the commuting "vectors" were established, which make up the connecting arcs between the municipalities of origin (residence) and destination (work / study), represented cartographically on Geographic Information Systems platforms by linear georeferenced features (polylines). 


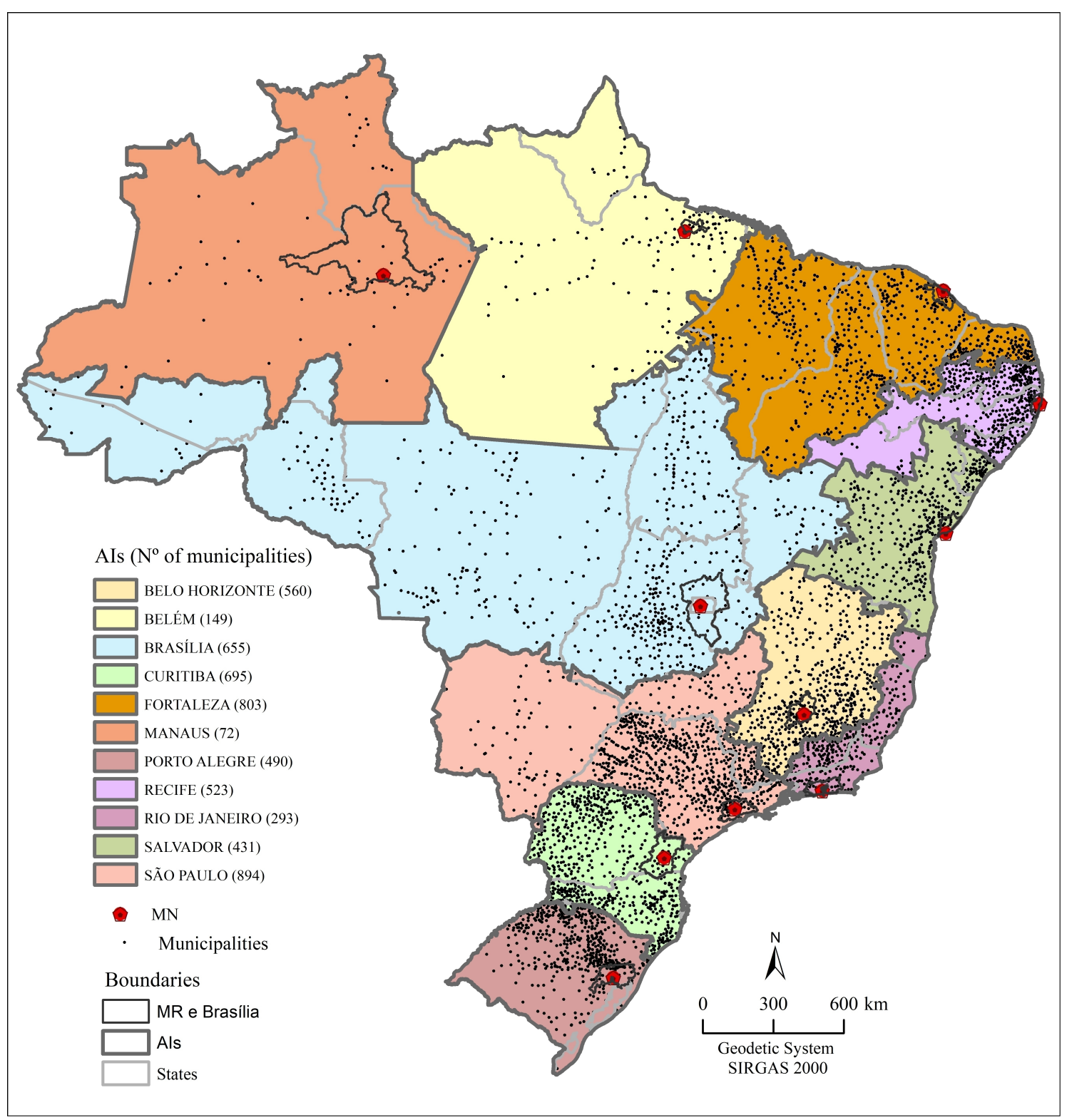

Figure 1: Areas of Influence (AIs) of the main Brazilian metropolises

Source: Extracted and adapted from IBGE (2007).

Although it may raise questions and controversies about the delimitation of the regions of influence established in this proposal, the use of AIs for spatial analysis allows us to evaluate and draw a precise picture of the real magnitude of the spatial mobility of the country's population. It also makes it possible to infer and evaluate the interdependent relationships established in space, in which the workforce and students' spatial movements play a relevant role, especially when confronted with the effects of recent migration 11. Taking the municipality as a unit of analysis, according to the political-administrative division in each period and the respective spatial aggregations (MN, PM, and IAI), it was possible to identify and map the mobility flows and vectors. The results, although limited to two census decades, may provide essential pointers to public administration, potentially useful for the elaboration of social and territorial planning policies, including those aimed at overcoming regional inequalities.

\section{THE PARTICIPATION OF MIGRATION IN COMMUTING}




\section{IN METROPOLITAN AIS: AN ANALYSIS AND INTERPRETATION OF RESULTS}

When analyzing the vectors and commuting flows, classified by the spatial groupings, with the origin and destination in the Metropolitan Nucleus (MN), the Metropolitan Periphery (PM) and the Interior of each Area of Influence (IAI), shown in Table 1, the most notable aspect is the drop in the relative share of the traditional PM $\rightarrow$ NM flows, which accounted for most of the commuting until the 1970s. Taken together, for the Brazilian AIs, this proportion dropped from $39.7 \%$ in 1980 to $25.7 \%$ in 2010. This percentage reduction was observed in most of these areas, except for Belém, Belo Horizonte and Curitiba, which showed a small growth. On the other hand, the considerable absolute and relative increase of commuting vectors with origin and destination in the municipalities of the 14 metropolitan AIs analyzed (IAI $\rightarrow$ IAI vectors) is striking. If in 1980 mobility in these vectors represented $32.6 \%$ of the regional total, in 2010 this proportion reached $49.4 \%$. However, there are noticeable differences when comparing the displacements in each AI. In the AIs of Salvador, Curitiba, Brasília, and Manaus, the participation of "extra-metropolitan" mobility exceeded 60\% in 2010. Part of the explanation for this stems from the existence of large urban centers outside their respective RMs, including the capital cities of neighboring states. Unlike these cases, in Belo Horizonte and Curitiba this proportion was around $33 \%$. In such cases, it seems that the effect of metropolitan primacy in each AI is still quite high.

Even though the increase in the number of commuting vectors within the AIs may be due to the demographic growth experienced in the period, especially from the second half of the last century, as well as the creation of new municipalities through emancipation, some numbers stand out: in 1980 the total number of IAI $\rightarrow$ IAI vectors was 34,378. In 2010 it reached 91,128, representing $2.8 \%$ of the possible connections in 2010 compared to $1.3 \%$ in 1980. In some AIs this share was over $6 \%$ in 2010, as in Rio de Janeiro, Belém and Manaus. In these last two, the high level of interaction is expected, given the smaller number of municipalities, which in many cases are geographically contiguous.

\begin{tabular}{|c|c|c|c|c|c|c|c|c|c|c|c|c|c|c|c|c|}
\hline \multirow{3}{*}{ AIs } & \multicolumn{16}{|c|}{1980} \\
\hline & \multicolumn{2}{|c|}{$\mathrm{MN} \rightarrow \mathrm{MP}$} & \multicolumn{2}{|c|}{$\mathrm{MN} \rightarrow \mathrm{IAI}$} & \multicolumn{2}{|c|}{$\mathrm{MP} \rightarrow \mathrm{MN}$} & \multicolumn{2}{|c|}{$\mathrm{MP} \rightarrow \mathrm{MP}$} & \multicolumn{2}{|c|}{$\mathrm{MP} \rightarrow \mathrm{IAI}$} & \multicolumn{2}{|c|}{$\mathrm{IAI} \rightarrow \mathrm{MN}$} & \multicolumn{2}{|c|}{$\mathrm{IAI} \rightarrow \mathrm{MP}$} & \multicolumn{2}{|c|}{$\mathrm{IAI} \rightarrow \mathrm{IAI}$} \\
\hline & $\mathrm{N}^{\circ}$ & $\%$ & $\mathrm{~N}^{\circ}$ & $\%$ & $\mathrm{~N}^{\circ}$ & $\%$ & $\mathrm{~N}^{\circ}$ & $\%$ & $\mathrm{~N}^{\circ}$ & $\%$ & $\mathrm{~N}^{\circ}$ & $\%$ & $\mathrm{~N}^{\circ}$ & $\%$ & $\mathrm{~N}^{0}$ & $\%$ \\
\hline Manaus & 129 & 6,57 & 282 & 14,37 & 304 & 15,49 & 0 & 0,00 & 18 & 0,92 & 828 & 42,18 & 27 & 1,38 & 375 & 19,10 \\
\hline Belém & 901 & 2,93 & 2.570 & 8,35 & \begin{tabular}{|l|l|}
10.123 \\
\end{tabular} & 32,91 & 949 & 3,08 & 1.241 & 4,03 & 6.216 & 20,21 & 886 & 2,88 & 7.876 & 25,60 \\
\hline Fortaleza & 1.231 & 1,02 & 3.058 & 2,54 & 14.376 & 11,94 & 839 & 0,70 & 1.014 & 0,84 & 12.457 & 10,34 & 574 & 0,48 & 86.889 & 72,14 \\
\hline Recife & 9.493 & 3.56 & 3.163 & 1,19 & 136.782 & 51,31 & 16.574 & 6,22 & 3.220 & 1,21 & 18.512 & 6.94 & 2.002 & 0,75 & 76.838 & 28,82 \\
\hline Salvador & 15.834 & 17,18 & 3.531 & 3,83 & 7.666 & 8,32 & 8.289 & 8,99 & 1.266 & 1,37 & 14.973 & 16,24 & 5.236 & 5,68 & 35.389 & 38,39 \\
\hline Belo Horizonte & 25.157 & 11,17 & 5.273 & 2,34 & 82.319 & 36,56 & 13.944 & 6,19 & 2.938 & 1,30 & 16.978 & 7,54 & 2.441 & 1,08 & 76.142 & 33,81 \\
\hline Rio de Janeiro & 14.320 & 1,66 & \begin{tabular}{|l|l}
5.148 \\
\end{tabular} & 0,60 & \begin{tabular}{|l|l}
523.719 \\
\end{tabular} & 60,70 & 126.327 & 14,64 & 11.453 & 1,33 & 14.999 & 1,74 & 3.990 & 0,46 & 162.823 & 18,87 \\
\hline São Paulo & 133.692 & 10,58 & 15.664 & 1,24 & 405.612 & 32,10 & 213.577 & 16,90 & \begin{tabular}{|c|}
10.170 \\
\end{tabular} & 0,80 & 47.300 & 3,74 & 12.646 & 1,00 & 425.121 & 33,64 \\
\hline Curitiba & 4.653 & 2,24 & 3.370 & 1,62 & 40.811 & 19,66 & 3.121 & 1,50 & 2.832 & 1,36 & 8.772 & 4,23 & 1.582 & 0,76 & 142.420 & 68,62 \\
\hline Porto Alegre & 12.623 & 5,01 & 2.418 & 0,96 & 123.018 & 48,78 & 52.425 & 20,79 & 3.709 & 1,47 & 9.898 & 3,92 & 6.501 & 2,58 & 41.605 & 16,50 \\
\hline Brasîilia & 618 & 0,91 & 780 & 1,15 & 1.857 & 2,73 & 126 & 0,19 & 202 & 0,30 & 13.246 & 19,47 & 495 & 0,73 & 50.703 & 74,53 \\
\hline Total & 218.651 & 6,45 & 45.257 & 1,33 & 1.346 .587 & 39,71 & 436.171 & 12,86 & 38.063 & 1,12 & 164.179 & 4,84 & 36.380 & 1,07 & 1.106 .181 & 32,62 \\
\hline \multirow{3}{*}{ AIs } & \multicolumn{16}{|c|}{2010} \\
\hline & \multicolumn{2}{|c|}{$\mathrm{MN} \rightarrow \mathrm{MP}$} & \multicolumn{2}{|c|}{$\mathrm{MN} \rightarrow \mathrm{IAI}$} & \multicolumn{2}{|c|}{$\mathrm{MP} \rightarrow \mathrm{MN}$} & \multicolumn{2}{|c|}{$\mathrm{MP} \rightarrow \mathrm{MP}$} & \multicolumn{2}{|c|}{$\mathrm{MP} \rightarrow \mathrm{IAI}$} & \multicolumn{2}{|c|}{$\mathrm{IAI} \rightarrow \mathrm{MN}$} & \multicolumn{2}{|c|}{$\mathrm{IAI} \rightarrow \mathrm{MP}$} & \multicolumn{2}{|c|}{$\mathrm{IAI} \rightarrow \mathrm{IAI}$} \\
\hline & $\mathrm{N}^{0}$ & $\%$ & $\mathrm{~N}^{\circ}$ & $\%$ & $\mathrm{~N}^{\circ}$ & $\%$ & $\mathrm{~N}^{\circ}$ & $\%$ & $\mathrm{~N}^{0}$ & $\%$ & $\mathrm{~N}^{0}$ & $\%$ & $\mathrm{~N}^{\circ}$ & $\%$ & $\mathrm{~N}^{\mathrm{0}}$ & $\%$ \\
\hline Manaus & 3.223 & 8,42 & 7.902 & 20,64 & 5.011 & 13,09 & 633 & 1,65 & 1.044 & 2,73 & 5.347 & 13,97 & 999 & 2,61 & 14.127 & 36,90 \\
\hline Belém & 14.735 & 5,33 & 12.380 & 4,48 & 104.763 & 37,92 & 14.194 & 5,14 & 8.761 & 3,17 & 16.563 & 5,99 & 6.323 & 2,29 & 98.569 & 35,68 \\
\hline Fortaleza & 22.638 & 2,56 & 16.615 & 1,88 & 102.477 & 11,59 & 32.974 & 3,73 & 5.695 & 0,64 & 28.848 & 3,26 & 5.254 & 0,59 & 669.807 & 75,74 \\
\hline Recife & 45.896 & 4,36 & 10.978 & 1,04 & 285.483 & 27,10 & 91.835 & 8,72 & 17.020 & 1,62 & 43.367 & 4,12 & 12.599 & 1,20 & 546.259 & 51,85 \\
\hline Salvador & 47.747 & 7,71 & 17.758 & 2,87 & 53.601 & 8,65 & 39.115 & 6,31 & 5.292 & 0,85 & 38.904 & 6,28 & 16.120 & 2,60 & 401.079 & 64,73 \\
\hline Belo Horizonte & 69.903 & 7,10 & 14.280 & 1,45 & 382.130 & 38,82 & 129.042 & 13,11 & 15.652 & 1,59 & 42.326 & 4,30 & 10.855 & 1,10 & 320.057 & 32,52 \\
\hline Rio de Janeiro & 63.310 & 3,48 & 16.606 & 0,91 & 643.391 & 35,37 & 369.505 & 20,31 & 28.123 & 1,55 & 47.847 & 2,63 & 19.907 & 1,09 & 630.509 & 34,66 \\
\hline São Paulo & 177.478 & 4,71 & 42.732 & 1,13 & 909.324 & 24,15 & 679.888 & 18,06 & 57.972 & 1,54 & 128.037 & 3.40 & 38.080 & 1,01 & 1.731 .563 & 45,99 \\
\hline Curitiba & 53.269 & 4,31 & 11.995 & 0,97 & 245.909 & 19,89 & \begin{tabular}{|l|l}
50.729 \\
\end{tabular} & 4,10 & 11.005 & 0,89 & 20.556 & 1.66 & 6.742 & 0,55 & 836.274 & 67,63 \\
\hline Porto Alegre & 38.319 & 4,50 & 10.009 & 1,17 & 251.775 & 29,56 & 209.353 & 24,58 & 21.970 & 2,58 & 18.366 & 2,16 & 21.183 & 2,49 & 280.908 & 32,97 \\
\hline Brasilia & 10.024 & 1,23 & 8.531 & 1,05 & 188.579 & 23,17 & 9.922 & 1,22 & 4.043 & 0,50 & 18.065 & 2,22 & 3.640 & 0,45 & 571.209 & 70,17 \\
\hline Total & 546.542 & \begin{tabular}{|l|}
4,43 \\
\end{tabular} & 169.786 & 1,38 & \begin{tabular}{|c|}
3.172 .443 \\
\end{tabular} & \begin{tabular}{|l|}
25,70 \\
\end{tabular} & \begin{tabular}{|c|}
1.627 .190 \\
\end{tabular} & 13,18 & 176.577 & 1,43 & 408.226 & 3,31 & 141.702 & 1,15 & \begin{tabular}{|l|l|}
6.100 .361 \\
\end{tabular} & 49,42 \\
\hline
\end{tabular}

Table 1: Percentage of Commuting according to origin and destination in the Metropolitan Nucleus (MN), Metropolitan Periphery (MP) and Inside each Area of Influence (IAI) - 1980 and 2010

Source: IBGE, 1980 and 2010 Demographic Census (sample data).

The cartograms in Figure 2, which represent the IAI $\rightarrow$ IAI vectors with a flow greater than 100 people, show the expansion of the commuting connections within the metropolitan AIs. When 
considering the densest mobility vectors, involving those with more than 10,000 people, there is strong growth in the period from 1980 to 2010 , from 41 to 91 . As expected, the mobility network connection level was much more intense in south-central Brazil, especially in the AIs of São Paulo, Rio de Janeiro, Brasilia, and Belo Horizonte. It is also worth highlighting the growth of vectors closer to metropolitan regions, including the northeast of the country. However, those lower density vectors with a flow of fewer than 1,000 people, which usually involve small and medium-sized municipalities, rose from 1,267 in 1980 to 9,003 in 2010. In many cases, they are very likely to involve non-urban mobilities, including those on old and new agricultural frontiers in the interior of the country.

On analyzing the commuting flows, discriminated by migratory condition and place of birth, as shown in Figure 3, the significant increase in the participation of non-migrant commuters in the decade is evident. In 1980 non-migrants accounted for $59.98 \%$ of commuting mobility, by 2010 that proportion had reached $76.85 \%$. Of this contingent, it is worth highlighting the growth in the participation of non-migrants from the municipality of residence, which went from $28.62 \%$ in 1980 to $42.48 \%$ in 2010 . This picture reveals that the intensification of commuting in all the metropolitan AIs, resulting from the continuous and increasingly fragmented and dispersed territorial expansion of these urban agglomerations, coincided with a period of significant reduction in interregional (especially interstate) migratory flows, which are known to have been important in the process of growth and expansion of metropolitan areas until at least the 1980s.

Regarding the behavior by AI, the case of São Paulo is noteworthy due to the dimensions of the numbers involved; the volume of non-migrants / natives rose from over 290 thousand in 1980 to over 1.4 million in 2010 (Table 2). In relative terms, the AIs of Recife and Salvador are more remarkable as they both account for the most intraregional displacements of non-migrant / native commuters. Thus, as already observed for the group of AIs directly associated with this change, there was a significant relative reduction of migrants in the period and non-native migrants in particular. In the national scenario, the participation of this group of commuters dropped from $38.42 \%$ in 1980 to $20.90 \%$ in 2010 (although there had been some growth overall). 

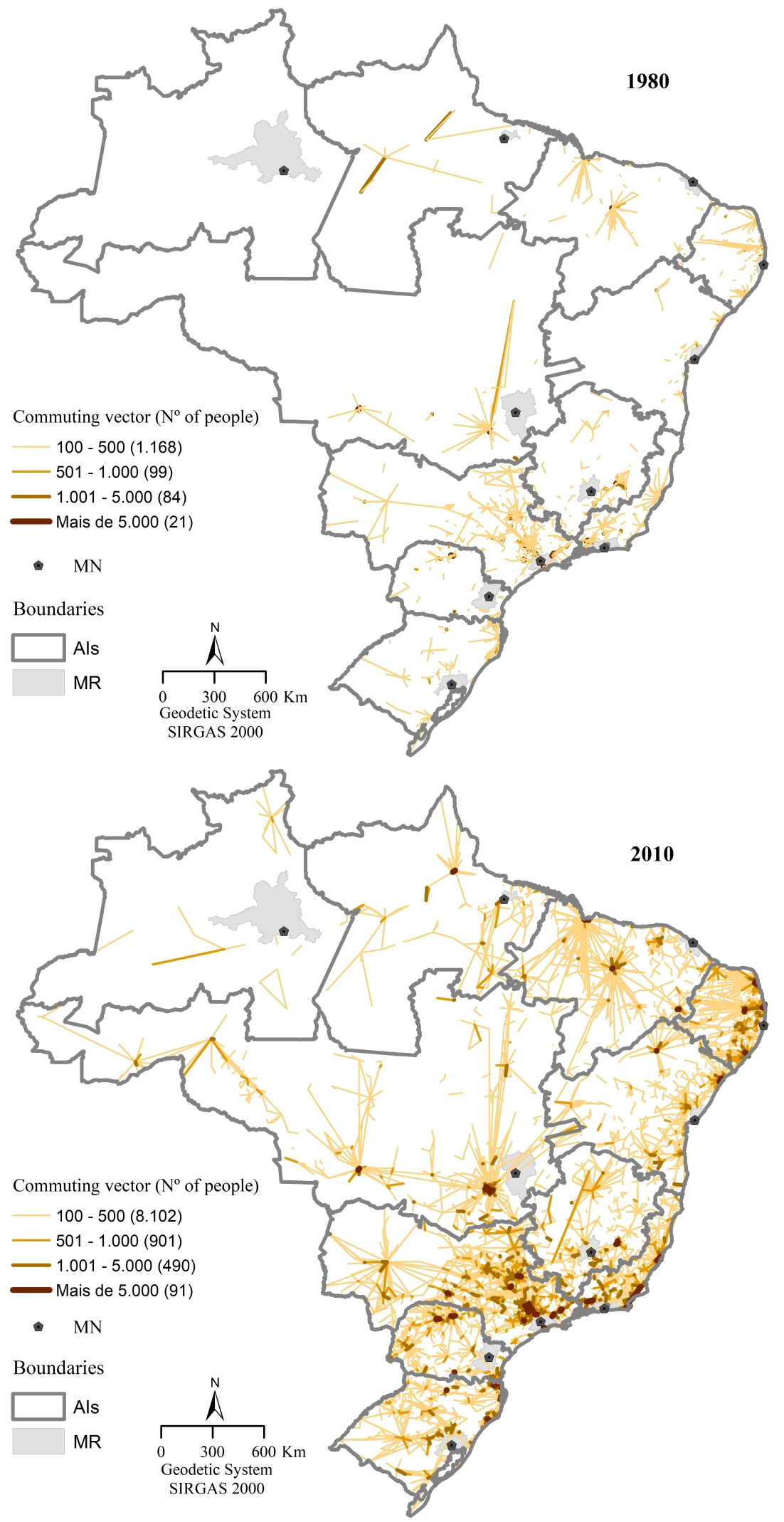

Figure 2: Commuting Vectors between the municipalities of each metropolitan AI,

$$
1980 \text { and } 2010(\text { IAI } \rightarrow \text { IAI flows })
$$

Source: IBGE, 1980 and 2010 Demographic Census (sample data). 
Note: Commuting vectors with a flow of over 100 people.

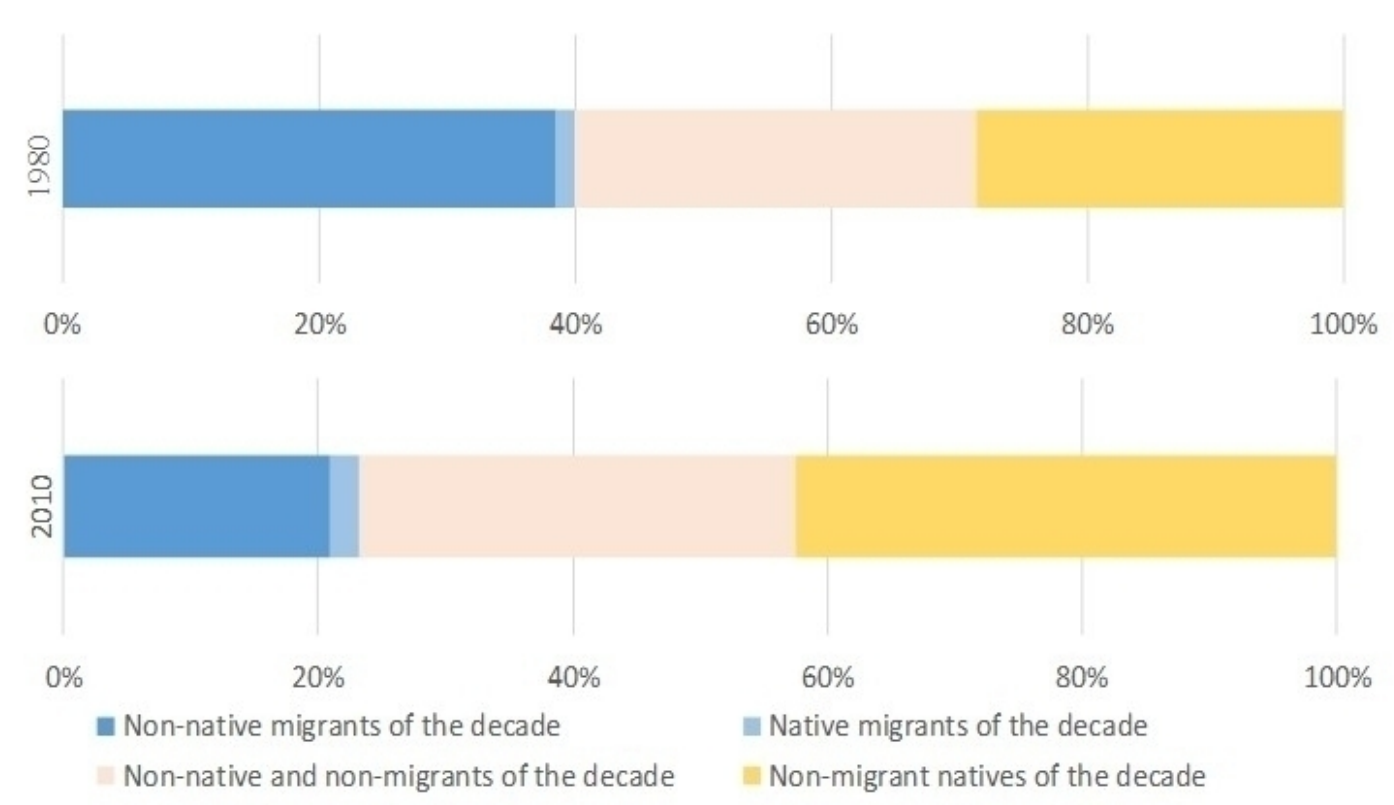

Figure 3: The proportion of migrants and non-migrants of the decade, discriminated by natives and non-natives of the municipality of residence, in commuting within the Brazilian metropolitan AIs, 1980 and 2010

Source: IBGE, 1980 and 2010 Demographic Census (sample data).

\begin{tabular}{|c|c|c|c|c|c|c|c|c|c|c|c|c|c|c|c|c|}
\hline \multirow{4}{*}{$\begin{array}{l}\text { AIs } \\
\text { Metropolitans }\end{array}$} & \multicolumn{8}{|c|}{ Migrants of the decade } & \multicolumn{8}{|c|}{ Non-migrants of the decade } \\
\hline & \multicolumn{4}{|c|}{ Non-native } & \multicolumn{4}{|c|}{ Native } & \multicolumn{4}{|c|}{ Non-native } & \multicolumn{4}{|c|}{ Native } \\
\hline & \multicolumn{2}{|c|}{$\mathrm{N}^{\circ}$} & \multicolumn{2}{|c|}{$\%$} & \multicolumn{2}{|l|}{$\mathrm{N}^{\circ}$} & \multicolumn{2}{|c|}{$\%$} & \multicolumn{2}{|c|}{$\mathrm{N}^{\circ}$} & \multicolumn{2}{|c|}{$\%$} & \multicolumn{2}{|c|}{$\mathrm{N}^{\circ}$} & \multicolumn{2}{|l|}{$\%$} \\
\hline & 1980 & 2010 & 1980 & 2010 & 1980 & 2010 & 1980 & 2010 & 1980 & 2010 & 1980 & 2010 & 1980 & 2010 & 1980 & 2010 \\
\hline Manaus & 309 & 8.849 & 15,7 & 23,1 & 18 & 1.277 & 0,9 & 3,3 & 396 & 11.367 & 20,2 & \begin{tabular}{|l|}
29,7 \\
\end{tabular} & 1.240 & 16.794 & 63,2 & 43,9 \\
\hline Belén & 12.544 & 67.153 & 40,8 & 24,3 & 468 & 5.586 & 1,5 & 2,0 & 5.696 & 100.038 & 18,5 & 36,2 & 12.054 & 103.513 & 39,2 & 37,5 \\
\hline Fortal & 35.732 & 181.069 & 29,7 & 20,5 & 3.442 & 23.121 & 2,9 & 2,6 & 19.387 & 242.561 & 16,1 & 27,4 & 61.877 & 437.556 & 51,4 & 49,5 \\
\hline Recife & 103.431 & 177.016 & 38,8 & 16,8 & 6.319 & 26.774 & 2,4 & 2,5 & 68.652 & 297.751 & 25,8 & 28,3 & 88.182 & 551.897 & 33,1 & 52,4 \\
\hline Salvac & 23.620 & 121.216 & 25,6 & 19,6 & 2.560 & 16.081 & 2,8 & 2,6 & 19.399 & 170.554 & 21,0 & 27,5 & 46.605 & 311.766 & 50,6 & 50,3 \\
\hline Belo F & 95.704 & 198.518 & 42,5 & 20,2 & 4.039 & 23.900 & 1,8 & 2,4 & 55.936 & 339.070 & 24,8 & 34,4 & 69.513 & 422.757 & 30,9 & 43,0 \\
\hline $\mathrm{Ri}$ & 396 & 306.600 & 30,4 & 16,9 & 24 & 81 & 1,2 & 2,1 & 347.320 & 582.566 & 40,3 & 32,0 & 242.339 & 892.653 & 28,1 & 49,1 \\
\hline & & 799.714 & 43 & 21,2 & $10.27 / 5$ & 77.376 & 1,3 & 2,1 & 418.016 & 1.449 .351 & 33,1 & 38,5 & 290.197 & 1.438 .633 & 23,0 & 38,2 \\
\hline Curitiba & & 298.419 & 43,6 & 24,1 & 4.490 & 30.197 & 2,2 & 2,4 & 43.486 & 425.272 & 21,0 & 34,4 & 69.181 & 482.590 & 33,3 & 39,0 \\
\hline Porto & 102.395 & 172.447 & 40,6 & 20,2 & 4.754 & 20.370 & 1,9 & 2,4 & 72.101 & 294.579 & 28,6 & 34,6 & 72.947 & 364.488 & 28,9 & 42,8 \\
\hline Brasili & 37.269 & 249.056 & 54,8 & 30,6 & 1.228 & 15.260 & 1,8 & 1,9 & 12.882 & 328.617 & 18,9 & 40,4 & 16.648 & 221.080 & 24,5 & 27,2 \\
\hline Total & 303.098 & 2.580 .057 & 38,4 & 20,9 & 54.317 & 277.323 & 1,6 & 2,2 & 1.063 .271 & 4.241 .726 & 31,4 & 34,4 & 970.783 & 5.243 .727 & 28.6 & 42,5 \\
\hline
\end{tabular}

Table 2: Number and percentage of non-native and native migrants and non-migrants of the decade who commuted in the AIs of the main Brazilian metropolises, 1980 and 2010

Source: IBGE, 1980 and 2010 Demographic Census (sample data).

The comparison of the participation of native non-migrants in the commuting in metropolitan AIs shows a higher weight when considering the IAI $\rightarrow$ IAI type vectors. While in 1980, native non-migrants accounted for $39.2 \%$, in 2010 , they accounted for $46.2 \%$ of the total in the country (Table 3 ). In certain AIs, such as Recife and Belo Horizonte, the proportion reached almost $60 \%$ in 2010 . For these same flows, migrants of the decade (non-native and native) involved less than 24 percent. Although in MP $\rightarrow$ MN type mobility the proportion of native non-migrants is relatively lower, it already represented 33.7\% in 2010 (in 1980 it was only 17.5\%). These figures make at least one aspect clear: that non-migrants from their respective municipalities are currently the main protagonists of commuting, especially in the "extra-metropolitan" context. The idea that commuting is a direct rebuttal 
of migration no longer seems sustainable and requires a growing relativization, particularly when comparing moments as different from the Brazilian migratory dynamics as the 1970s (reflected in the 1980 Census) and the 2000s (revealed in the 2010 Census)12.

\begin{tabular}{|c|c|c|c|c|c|c|c|c|c|c|c|c|c|c|c|c|}
\hline \multicolumn{17}{|c|}{$\mathrm{IAI} \rightarrow \mathrm{IAI}$} \\
\hline \multirow{4}{*}{$\begin{array}{l}\text { AIs } \\
\text { Metropolitans }\end{array}$} & \multicolumn{8}{|c|}{ Migrants of the decade } & \multicolumn{8}{|c|}{ Migrants of the decade } \\
\hline & \multicolumn{4}{|c|}{ Non-native } & \multicolumn{4}{|c|}{ Native } & \multicolumn{4}{|c|}{ Non-native } & \multicolumn{4}{|c|}{ Native } \\
\hline & \multicolumn{2}{|c|}{$\mathrm{N}^{\circ}$} & \multicolumn{2}{|c|}{$\%$} & \multicolumn{2}{|c|}{$\mathrm{N}^{\circ}$} & \multicolumn{2}{|c|}{$\%$} & \multicolumn{2}{|c|}{$\mathrm{N}^{\circ}$} & \multicolumn{2}{|c|}{$\%$} & \multicolumn{2}{|c|}{$\mathrm{N}^{\circ}$} & \multicolumn{2}{|c|}{$\%$} \\
\hline & 1980 & 2010 & 1980 & 2010 & 1980 & 2010 & 1980 & 2010 & 1980 & 2010 & 1980 & 2010 & 1980 & 2010 & 1980 & 2010 \\
\hline Manaus & 82 & 3.303 & 21,9 & 23,4 & 4 & 434 & 1,1 & 3,1 & 97 & 3.992 & 25,9 & 28,3 & 192 & 6.399 & 51,2 & 45,3 \\
\hline Belém & 2.725 & 23.628 & 34,6 & 24,0 & 111 & 2.253 & 1,4 & 2,3 & 1.429 & 29.206 & 18,1 & 29,6 & 3.611 & 43.482 & 45,8 & 44,1 \\
\hline Fortaleza & 24.319 & 137.707 & 28,0 & 20,6 & 2.603 & 17.958 & 3,0 & 2,7 & 13.995 & 171.123 & 16,1 & 25,5 & 45.972 & 343.019 & 52,9 & 51,2 \\
\hline Recife & 20.806 & 87.030 & 27,1 & 15,9 & 2.484 & 16.914 & 3,2 & 3,1 & 16.697 & 122.994 & 21,7 & 22,5 & 36.851 & 319.322 & 48,0 & 58,5 \\
\hline Salvador & 9.471 & 71.909 & 26,8 & 17,9 & 977 & 11.294 & 2,8 & 2,8 & 6.823 & 104.305 & 19,3 & 26,0 & 18.118 & 213.572 & 51,2 & 53,2 \\
\hline Belo Horizonte & 21.428 & 48.768 & 28,1 & 15,2 & 2.085 & 10.474 & 2,7 & 3,3 & 17.340 & 70.410 & 22,8 & 22,0 & 35.289 & 190.405 & 46,3 & 59,5 \\
\hline Rio de Janeiro & 62.098 & 134.003 & 38,1 & 21,3 & 3.425 & 14.357 & 2,1 & 2,3 & 44.257 & 202.492 & 27,2 & 32,1 & 53.043 & 279.658 & 32,6 & 44,4 \\
\hline São Paulo & 152.413 & 362.276 & 35,9 & 20,9 & 8.683 & 34.232 & 2,0 & 2,0 & 118.099 & 600.287 & 27,8 & 34,7 & 145.926 & 734.768 & 34,3 & 42,4 \\
\hline Curitiba & 53.674 & 201.576 & 37,7 & 24,1 & 3.635 & 22.537 & 2,6 & 2,7 & 30.373 & 257.010 & 21,3 & 30,7 & 54.738 & 355.151 & 38,4 & 42,5 \\
\hline Porto Alegre & 8.230 & 55.060 & 19,8 & 19,6 & 1.443 & 9.843 & 3,5 & 3,5 & 6.249 & 63.780 & 15,0 & 22,7 & 25.683 & 152.226 & 61,7 & 54,2 \\
\hline Brasília & 25.622 & 164.743 & 50,5 & 28,8 & 882 & 11.767 & 1,7 & 2,1 & 10.520 & 216.417 & 20,7 & 37,9 & 13.679 & 178.282 & 27,0 & 31,2 \\
\hline Total & 380.868 & 1.290 .003 & 34,4 & 21,1 & 26.332 & 152.063 & 2,4 & 2,5 & 265.879 & 1.842 .016 & 24,0 & 30,2 & 433.102 & 2.816 .284 & 39,2 & 46,2 \\
\hline \multirow{5}{*}{$\begin{array}{l}\text { AIs } \\
\text { Metropolitans }\end{array}$} & \multirow{2}{*}{\multicolumn{8}{|c|}{$\mathrm{MP} \rightarrow \mathrm{MN}$}} & & & & & & & & \\
\hline & & & & & & & & & \multicolumn{8}{|c|}{ Migrants of the decade } \\
\hline & \multicolumn{4}{|c|}{ Non-native } & \multicolumn{4}{|c|}{ Native } & \multicolumn{4}{|c|}{ Non-native } & \multicolumn{4}{|c|}{ Native } \\
\hline & \multicolumn{2}{|c|}{$\mathrm{N}^{\circ}$} & $\%$ & & $\mathrm{~N}^{\circ}$ & & $\%$ & & $\mathrm{~N}$ & $r^{\circ}$ & $\%$ & & $\mathrm{~N}$ & $0^{\circ}$ & $\%$ & \\
\hline & 1980 & 2010 & 1980 & 2010 & 1980 & 2010 & 1980 & 2010 & 1980 & 2010 & 1980 & 2010 & 1980 & 2010 & 1980 & 2010 \\
\hline Manaus & 52 & 1.390 & 17,1 & 27,7 & 0 & 69 & 0,0 & 1,4 & 69 & 1.476 & 22,7 & 29,5 & 183 & 2.075 & 60,2 & 41,4 \\
\hline Belém & 6.754 & 28.582 & 66,7 & 27,3 & 94 & 1.225 & 0,9 & 1,2 & 1.938 & 49.333 & 19,1 & 47,1 & 1.337 & 25.623 & 13,2 & 24,5 \\
\hline Fortaleza & 7.258 & 24.800 & 50,5 & 24,2 & 264 & 1.236 & 1,8 & 1,2 & 1.904 & 40.738 & 13,2 & 39,8 & 4.950 & 35.703 & 34,4 & 34,8 \\
\hline Recife & 66.858 & 51.787 & 48,9 & 18,1 & 2.121 & 4.354 & 1,6 & 1,5 & 39.578 & 112.895 & 28,9 & 39,5 & 28.225 & 116.448 & 20,6 & 40,8 \\
\hline Salvador & 3.619 & 20.164 & 47,2 & 37,6 & 400 & 581 & 5,2 & 1,1 & 1.376 & 20.316 & 17,9 & 37,9 & 2.271 & 12.541 & 29,6 & 23,4 \\
\hline Belo Horizonte & 51.631 & 95.000 & 62,7 & 24,9 & 778 & 5.835 & 0,9 & 1,5 & 18.941 & 171.867 & 23,0 & 45,0 & 10.969 & 109.429 & 13,3 & 28,6 \\
\hline Rio de Janeiro & 154.824 & 88.814 & 29,6 & 13,8 & 4.494 & 10.708 & 0,9 & 1,7 & 239.601 & 220.302 & 45,7 & 34,2 & 124.800 & 323.568 & 23,8 & 50,3 \\
\hline São Paulo & 225.299 & 213.174 & 55,5 & 23,4 & 2.359 & 15.949 & 0,6 & 1,8 & 138.571 & 412.501 & 34,2 & 45,4 & 39.383 & 267.701 & 9,7 & 29,4 \\
\hline Curitiba & 28.236 & 64.285 & 69,2 & 26,1 & 419 & 3.915 & 1,0 & 1,6 & 6.785 & 111.328 & 16,6 & 45,3 & 5.371 & 66.380 & 13,2 & 27,0 \\
\hline Porto Alegre & 62.336 & 50.997 & 50,7 & 20,3 & 1.354 & 2.932 & 1,1 & 1,2 & 41.963 & 112.534 & 34,1 & 44,7 & 17.365 & 85.312 & 14,1 & 33,9 \\
\hline Brasília & 1.045 & 70.841 & 56,3 & 37,6 & 52 & 1.796 & 2,8 & 1,0 & 192 & 92.851 & 10,3 & 49,2 & 568 & 23.091 & 30,6 & 12,2 \\
\hline Total & 607.912 & 709.834 & 45,1 & 22,4 & 12.335 & 48.600 & 0,9 & 1,5 & 490.918 & 1.346 .141 & 36,5 & 42,4 & 235.422 & 1.067 .871 & 17,5 & 33,7 \\
\hline
\end{tabular}

Table 3: Number and percentage of native and non-native migrants and non-migrants of the decade in Commuting Mobility, broken down by origin and destination in the municipalities of the interior of the AIs (vectors IAI $\rightarrow$ IAI) and origin in the Periphery and destination in the Metropolitan Nucleus

$($ vectors $\mathrm{MP} \rightarrow \mathrm{MN}), 1980$ and 2010

Source: IBGE, 1980 and 2010 Demographic Census (sample data).

\section{CONSIDERATIONS AND CONCLUSION}

The debate on the magnitude and significance of the population's spatial mobility has become recurrent in recent years, partly as a result of the explanatory power and consequences inherent in the dynamics of the Brazilian population, marked by the recent process of demographic transition. Many uncertainties remain about the prevalence of certain patterns or trends of the spatial distribution of the Brazilian population, resulting from different forms of mobility. However, the belief in the supposed reversal of polarization, as well as the hypothesis of spatial deconcentration, as suggested by some authors and proposed in the classical models of the regional economy, have been inappropriate to the analysis of the Brazilian case. The slowdown in the population growth rate of the main metropolises has not represented a loss in their territorial management functions, which requires further evaluation of the effects of migration and commuting.

The synthesis of the empirical results presented in this paper permits some general conclusions to be drawn. The first is that commuting in the "extra-metropolitan" space has experienced a higher level of both absolute and relative growth, more than the traditional flow to the metropolis' periphery. Also, commuting does not appear to be a phenomenon favored primarily by migrants of the decade, regardless of whether they are native to the municipalities of residence (although migrants also represent a fairly 
significant volume). Lastly, even among commuters living in the peripheral municipalities, who travel regularly to the metropolitan nucleus, the participation of non-migrants is not the most significant.

It is worth emphasizing that, to a large extent, the growth of non-migrants in the composition of metropolitan commuting seems to be a direct effect of the reduction of the weight of migration on intra-regional and inter-regional demographic dynamics, although the indirect effects may be inferred from the time of residence in the municipality of residence. Thus, it is plausible to assume that part of the commuting mobility of native non-migrants involves the offspring of migrants from previous decades, born in the municipalities of current residence.

In addition to the empirical findings themselves, it is essential to highlight the possibilities and potentialities offered to studies on spatial mobility of the population at the regional level, especially when the variables that allow the identification of participation in migration are combined. The analysis of stocks and flows of people, evaluated by the cut established by the metropolitan AIs, allows the incorporation of the demographic aspects of the urban-regional organization in the country. It also provides evidence on the social and economic links shaping the city network at the regional level, whether considered in a more specific (urban network) or a broader sense (geographical network). In either case, it displays a synthetic and approximate picture of the relationships established between the spatial mobility of the population and the role of old and new regional centralities.

\section{ACKNOWLEDGMENTS}

The authors are grateful to the $\mathrm{CNPq}$, for the senior postdoctoral scholarship, whose research project is developed at NEPO / UNICAMP.

\section{NOTES}

I However, as Faria (1991) has pointed out, the growing volume of the urban population was not restricted to a small number of large centers, as occurred in other undeveloped countries. In fact, the urbanization process in Brazil between 1950 and 1980 had dual characteristics. According to the same author, on the one hand, large population contingents were concentrated in a small number of metropolitan areas and large cities, such as Rio de Janeiro and São Paulo. On the other hand, it fueled the growth of the urban population of a large number of cities of different sizes that fit into a complex pattern of territorial division of social labor, both in the countryside and between cities (Faria 1991).

II Thus, as presented by Ojima (2011), there are two options: 1) Pre-define the territorial boundary in question (municipality A, metropolitan region B, etc.) and seek to analyze the urban sprawl and population displacements within this cutout; or 2) Use population displacements to define the extent of the territory that should be considered as the study cutout.

III In assessing the French case and analyzing the metropolitan areas of Paris, Lyon and Marseille, Aguilera (2005) noted that over the past decade, changes in the location of jobs and people have led to employment growth, even though there has been a drop in the number of resident workers. The results obtained by this author, in this same work, allowed us to identify an increase in the number of commuting journeys between the subcenters and between some municipalities located outside the metropolitan area, which expand the average commuting distance. In the Brazilian case, as demonstrated by Cunha (2015), studies based on data from the 1980 Census had already clearly indicated this relationship.

IV Commuting can also involve another type of urban setting: involving the mobility of high-income families / people, who live in so-called gated communities and commute to other surrounding municipalities to work or study. This phenomenon includes the search for a better quality of life, especially for environmental amenities, including the condition of less violence in certain smaller municipalities. In this respect, it can also be considered that commuting is a consequence of metropolitan mobility determined by the expansion of the expansion vectors of the urban fabric of the metropolitan core.

V There is, as Ojima (2010, p.398) clarifies, "an almost immediate association of the process of metropolization with the emergence of 'dormitory cities', based on the dichotomous 'center-periphery' model"'. 
VI Furthermore, in the investigation of the coordination of management centers, in addition to the axes of public management and business management, health services were also considered.

VII In fact, the Rio de Janeiro MR was created the following year, instituted by Complementary Law No. 20 of July 1, 1974.

VIII These two censuses allow us to evaluate two highly relevant decades on the national demographic and migratory dynamics, which marked the consolidation of the Brazilian demographic transition. It is also worth remembering that the variable that identifies the municipality of work and / or study was excluded from the 1991 census survey.

IX The declared municipalities of study and work, broken down separately in the 2010 census, were aggregated to allow comparison with 1980 census data to identify displacements with the dual purpose of work and / or study. In cases where the person stated that he works in one municipality and studies in another, the working municipality code prevailed.

X For more details on how to use census requirements to study migration, see Rigotti (2011).

XI Although the urbanization process is recent in Brazil, data from the last two demographic censuses allowed some authors to indicate signs of spatial dispersion of the population, despite the fact that the main metropolises, even with very low growth, still maintain a strong regional demographic expression and continue to attract thousands of migrants from depressed regions (MARTINE, 1994; DINIZ, 1993; MATOS, 1995; LOBO, 2009, LOBO and MATOS, 2011). Data on population commuting within the Belo Horizonte Metropolitan Region (RMBH) and the Paulista Macro-Metropolis (CUNHA et al., 2013) also confirm this trend. Several studies have shown that since the 1970s, many municipalities in the metropolitan periphery have experienced high population growth, often resulting from the large volume of migrants originating from the metropolitan nucleus (LOBO et al., 2015).

XII For more details on changes in the Brazilian migration process since the 1960s, see Cunha (2015).

\section{REFERENCE}

AZZONI, C. Indústria e reversão da polarização no Brasil. Ensaios Econômicos, São Paulo, IPE/USP, n. $58,1986$.

BRITO, F.; SOUZA, J. de. Expansão Urbana nas grandes metrópoles: o significado das migrações intrametropolitanas e da mobilidade pendular na reprodução da pobreza. São Paulo em Perspectiva, v.19, n.4, p. 48-63, out/dez. 2005.

CARVALHO, J.; RIGOTTI, J. I. R.Os dados censitários brasileiros sobre migrações internas: algumas sugestões para análise. In: XI Encontro Nacional de Estudos Populacionais da ABEP.

CHAMPION, A. G. Population Change and Migration in Britain since 1981: Evidence for Continuing Deconcentration,Environment and Planning A, October, n. 26: p.1501-1520, 1994.

CHAMPION, A. G. Recent change in the pace of population deconcentration in Britain, Geoforum, v. 18, n. 4, p. 379-401, 1987.

CUNHA, J. M. P.(Org.) Dinâmicademográfica e socioespacial no BrasilMetropolitano: convergências e especificidadesregionais. Editora UFSCAR. São Carlos, 2018.

CUNHA, J.M.P. Dinâmicademográfica e migratória 1991-2010: realidades e mitos. IN: Marques, E(Org.) As transformações de São Paulo nosanos 2000. São Paulo: Editora UNESP, 2015, pp.107-146.

CUNHA, J. M. P. Mobilidadepopulacional e expansãourbana: o caso da RegiãoMetropolitana de São Paulo. Campinas, SP: LibrumEditora, 2015.

CUNHA, J. M. P da et al. Movimentospendularesna MMP. Relatório de pesquisa de apoio à elaboração do Plano de Ação da MacrometrópolePaulista (PAM). São Paulo, Nepo-Unicamp/Fundap/Emplasa, 2013.

DINIZ, C. C. Desenvolvimento poligonal noBrasil; nem desconcentração, nem contínuapolarização.

Nova Economia, Belo Horizonte,v. 31, n. 11, p. 35-64, set. 1993. 
IBGE. Regiões de influência das cidades 2007- REGIC 2007. Rio de Janeiro: IBGE, 2008.

LENCIONI, S. Cisão territorial da indústria e integração regional no estado de SãoPaulo.

BRANDÃO, C.; GALVÃO, A.C.; GONÇAL VES, M. F . (orgs.) Regiões ecidades, cidades nas regiões: o desafio urbano-regional. São Paulo: Ed. Unesp, 2000.

LIMONAD, E. Urbanização dispersa mais uma forma de expressão urbana? RevistaFormação， n. 14 , v.1,2007, p. 31-45.

LIPSHITZ, G. Spatial Concentration and Deconcentration of Population: Israel as a Case Study.

Geoforum. v. 27. N. 1, p. 87-96, 1996.

LOBO, C. Dispersão espacial da população nas Regiões de Influência das principais metrópoles brasileiras. Tese (Doutoradoem Geografia), Instituto de Geociências,Universidade Federal de Minas Gerais, BeloHorizonte, 2009.

LOBO, C.et al. Expanded commuting in the metropolitan region of Belo Horizonte: evidence for reverse commuting. Revista Brasileira de Estudos Populacionais, 2015, vol.32, no.2, p.219-233.

LOBO, C.e MATOS, R. Migrações e a dispersão espacial da população nas regiões de Influência das principais metrópoles Brasileiras. Revista Brasileira de Estudos Populacionais, 2011, vol.28, n.1, pp. 81-101.

LOBO, C.e MATOS, R. Dispersão espacial da população e do emprego formal nas regiões de influência do Brasil contemporâneo. Cadernos Metrópole, São Paulo, v. 12, n. 24, pp. 309-330, jul/dez 2010.

MAGALHÃES, F. Da metrópole à cidade-região: na direção de um novo arranjo espacial metropolitano? R. B. Estudos Urbanos e Regionais, v. 10, $\mathrm{n}^{\mathrm{o}} 2.2008$

MARTINE, G. A redistribuição espacial da população brasileira durante a década de 80 . Brasília: Ipea, 1994.

MATOS, R.; LOBO, C.; STEFANI, J. Pobreza urbana e a dimensão sócioespacial nos processos de redistribuição da população em periferias de Belo Horizonte. In: III Encontro Nacional sobre Migrações Internas. Campinas: ABEP/UNICAMP, 2003.

MATOS, R. Questões teóricas acerca dos processosde concentração e desconcentraçãoda população no espaço. Revista Brasileirade Estudos de População, São Paulo,p. 35-58, 1995.

OJIMA, R. Fronteiras metropolitanas: um olhar a partir dos movimentos pendulares. Revista

Paranaense de Desenvolvimento, Curitiba, n.121, 2011, p.115-132.

OJIMA, R.; MARANDOLA JR, E.; PEREIRA, R. H. M.; DA SILVA, R. B. O estigma de morar longe da cidade: repensando o consenso sobre as "cidades-dormitório" no Brasil. Cadernos metrópole, v. 12, n. 24, 2010, p. 395-415.

PACHECO, C. A. e PATARRA, N. Movimentosmigratórios anos 80: novos padrões? In:PATARRA, N. (Org.). Migração, condiçõesde vida e dinâmica urbana. Campinas:Unicamp, 1997, p. 25-72.

RAVENSTEIN, E. G. Leis da migração. In: MOURA, H. (Coord.). Migração interna: textos selecionados. Fortaleza: BNB, ETENE, 1980. p. 22-88.

REIS, N. G. Notas sobre urbanização dispersa e novas formas de tecido urbano. São Paulo: Via das Artes, 2006.

RICHARDSON, H. W. Polarization reversal in developing countries. The Regional Science Association Papers. Los Angeles, v. 45, p. 67-85, Nov. 1980.

RIGOTTI, J. I. R. Dados censitários e técnicas de análise das migrações no Brasil: avanços e lacunas. IN: CUNHA (ORG.) Mobilidadeespacial da população: desafiosteóricos e metodológicos para o seuestudo. NEPO/UNICAM, Campinas, 2011.

RIGOTTI, J. I. R.Fluxos Migratórios e Distribuição Espacial da População na Região Metropolitana de Belo Horizonte na década de 70. 1994. 119f. Dissertação de Mestrado em Demografia - Universidade Federal de Minas Gerais - Centro de Desenvolvimento e Planejamento 
Regional, Belo Horizonte.

SILVA, K. A. A., CUNHA, J.M.P. e ORTEGA, G. M. Um olhar demográfico sobre a constituição da macrometrópole paulista: fluxos populacionais, integração e complementaridade. Cadernos Metrópole, Vol. 19, 2017 (n. 40), 721-748. 